\title{
Arc and mantle detritus in the post-collisional, Lower Silurian Kabadah Formation, Lachlan Orogen, New South Wales
}

\author{
L. M. BARRON ${ }^{1 *}$, S. MEFFRE ${ }^{2}$ AND R. A. GLEN $^{1}$
}

'Geological Survey of New South Wales, Department of Primary Industries, PO Box 344, Hunter Regional Mail Centre, NSW 2310, Australia.

${ }^{2}$ ARC Centre of Excellence in Ore Deposits, University of Tasmania, Private Bag 79, Hobart, Tas. 7001, Australia.

\begin{abstract}
The Kabadah Formation outcrops in central New South Wales as a thrust package $66 \mathrm{~km}$ long, interleaved with Lower Silurian Canowindra Volcanics and situated between the Junee-Narromine and Molong Volcanic Belts of the Ordovician Macquarie Arc. The Kabadah Formation contains Early Silurian corals and Llandovery graptolites. Its provenance is complex, with detrital fragments of maficintermediate volcanic rocks, free crystals of pyroxene, chromite and ultramafic clasts, detrital volcanic quartz, garnet, and clasts of welded S-type rhyolitic volcanic rocks; and rare clasts from uplifted foldbelt rocks (granite and metamorphosed and deformed sediments). The variety of these clasts suggests that the Kabadah Formation records the Benambran collision of the Macquarie Arc with Ordovician quartz-rich sedimentary rocks, with detritus also derived from coeval Early Silurian mafic and felsic magmatism. The major source of detritus was from the short-lived emergent Fifield arc that formed from the subduction of an older backarc basin. The Kabadah Formation accumulated in an upwardshallowing Early Silurian marine basin between phases of the Benambran Orogeny.
\end{abstract}

KEY WORDS: Benambran Orogeny, chromite, Kabadah Formation, Lachlan Orogen, Macquarie Arc, Silurian, supra-subduction zone.

\section{INTRODUCTION}

This study investigates the provenance and tectonic setting of the Kabadah Formation, an Early Silurian largely volcaniclastic unit (Morgan et al. 1999) located between the Junee-Narromine and Molong Volcanic Belts of the Ordovician Macquarie Arc, in the Eastern subprovince of the Lachlan Orogen, central New South Wales (Figures 1, 2). The Kabadah Formation has a high aeromagnetic and high K-radiometric character that is similar to some Ordovician arc rocks in the district. As a result of this, and the presence of Ordovician fossils in a cherty portion, the Kabadah Formation was previously mapped as containing Ordovician to Silurian arc-derived sediments, and was inferred to be part of the basement to the Silurian-Devonian Cowra Trough (Pogson \& Watkins 1998; Meakin \& Morgan 1999).

However, most of the formation was deposited in shallow water, locally has a marly matrix, and carries fragments of coral fossils and algal mats, as well as graptolites, trilobites, brachiopods and cephalopods (corals and graptolites identified by L. Sherwin and reported in Meakin \& Morgan 1999). These fossils indicate an early Llandovery (Early Silurian) age for the shallow-water sediments, and the present research only deals with these rocks and their on-strike equivalents. Now placed in other formations are deep-water andesitic volcaniclastic sediments and cherts carrying Ordovician fossils (Percival \& Glen 2007), and an area of intrusive rocks near Yeoval.

The revised Kabadah Formation (Figure 2) has maximum development near GR 663000 m 6379000 m (AGD66) on the Wellington 1:100 000 map sheet. The formation occurs in an inferred west-dipping imbricate thrust package, occupying four separate but closely spaced narrow belts (Figure 2). Bedding, cross-bedding and grading indicate the rocks young westward, with shallow to intermediate westward dips throughout the formation. Locally, towards the eastern margins of some individual belts, bedding dips steeply east but is overturned, consistent with a west-dipping thrust package (Scott et al. 1997).

Barron and Warren (1998) reported detrital peridotite clasts and relatively abundant detrital translucent chromite from the Kabadah Formation, a mineral that is otherwise extremely rare in rocks from the region. The only other known occurrence of detrital chromite in sedimentary rocks of similar age is the presence of five grains of red-brown translucent chromite in two samples from the late Wenlock Mumbidgil Formation, Forbes Group near Forbes (GR 595750 m 63313550 m

*Corresponding author and present address: 7 Fairview Place, St Ives, NSW 2075, Australia (barronjandl@optusnet.com.au). 


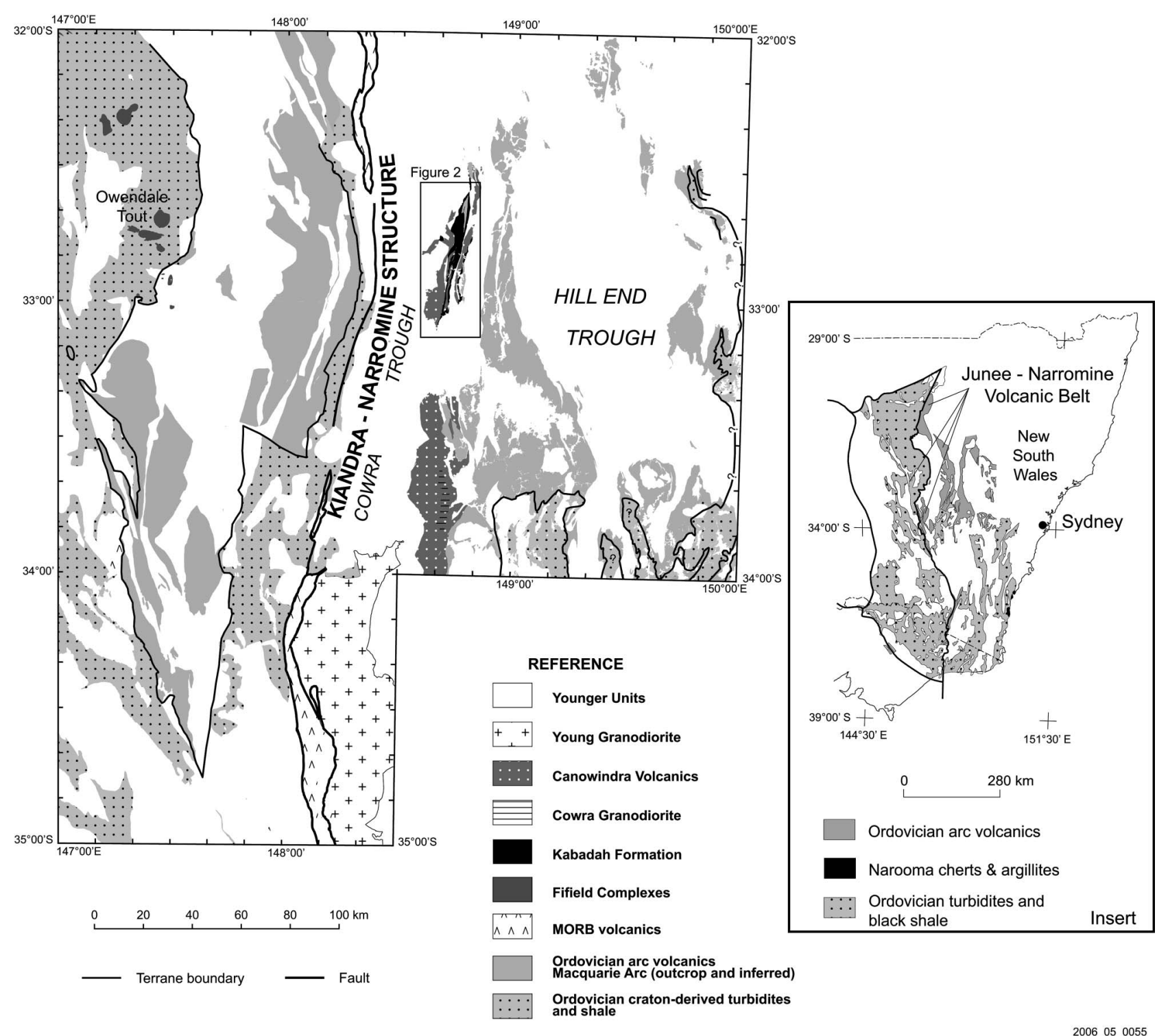

Figure 1 Geology of the central Lachlan Orogen (after Glen et al. 2007), with inset box marking the location of Figure 2. Owendale and Tout are two Fifield complexes mentioned in the text.

AGD66, $65 \mathrm{~km}$ southwest of the Kabadah Formation). The Kabadah Formation is located a considerable distance from known exposures of mantle rocks, being more than $185 \mathrm{~km}$ north of the Coolac Serpentinite Belt $\left(34^{\circ} 58^{\prime} \mathrm{S}, 148^{\circ} 06^{\prime} \mathrm{E}\right)$, and $120 \mathrm{~km}$ east of serpentinite exposed at Honeybugle $\left(31^{\circ} 48^{\prime} \mathrm{S}, 146^{\circ} 53^{\prime} \mathrm{E}\right)$.

Morgan et al. (1999) showed that the Kabadah Formation fines and shallows upward. The lower part involved turbiditic deposition of finer grained sediments, some of which are graptolitic, and debris flows of conglomerate and poorly sorted lithic sandstone. The large size of heavy-mineral grains, together with angularity of coral detritus, indicates there was little reworking, except towards the top of the formation, where magnetite-rich heavy-mineral sandstone occurs. A key discovery of Barron and Warren (1998) was that some chromite grains were trapped during growth of the shallowest water fossils, requiring an exposed abovewater source for this critical detritus.
Techniques employed in this work are described in Appendix 1, and the location of the analysed samples is given in Appendix 2.

\section{SAMPLING}

The 140 samples collected in this study comprise about $4 \%$ siltstone, $9 \%$ fine sandstone, $80 \%$ coarse sandstone (to $4 \mathrm{~mm}$ ) and $7 \%$ conglomerate. The sampling was performed in three stages: first, with a widely spaced regional survey, which provided localities with detrital chromite. This was followed by two stages of more detailed sampling around sample locations where detrital chromite was found to be abundant. As a result, the samples are biased towards coarse sandstones that are prominent around the two key areas of Yallundry and Buckingbah (Figure 2). Away from these two key areas, siltstone makes up at least $30 \%$ of the sequence. 


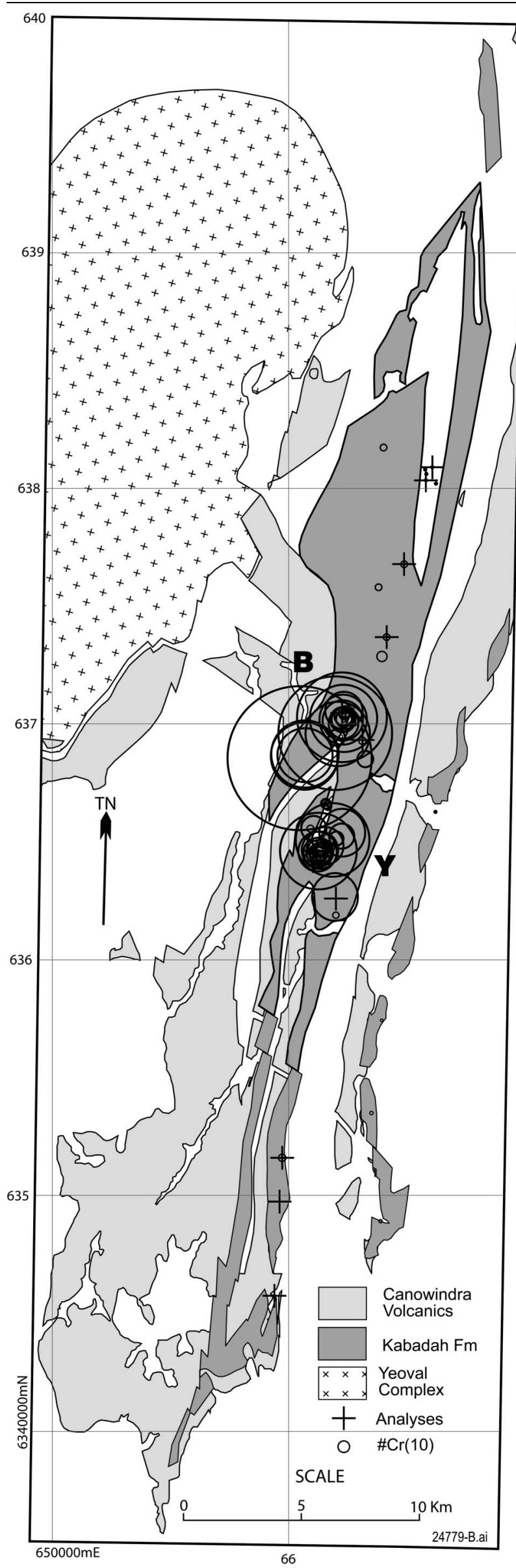

\section{MINERAL AND LITHIC DETRITUS}

\section{Nature and distribution}

The samples are predominantly moderately to poorly sorted closed-framework sandstones, with a muddy to limy matrix. The framework lithic clasts are typically rounded, with the larger $(4 \mathrm{~mm})$ grains being rock fragments, whereas smaller fragments are a mixture of rock and igneous crystal fragments. Rock fragments include dominant basaltic to trachytic volcanics, with local concentrations of detritus from reef corals, peridotite, cordierite - garnet-bearing rhyolitic welded tuff and minor limestone. Most samples have rare detritus derived from a deformed/uplifted fold-belt source region, including granite, deformed vein quartz, quartzite, foliated amphibolite, and deformed and metamorphosed sandstone.

The peridotite clasts are soft, black, angular grains $2-20 \mathrm{~mm}$ across with ragged margins. All have been altered to chlorite. Although generally rare, in the Buckinbah area, they reach modal abundances of 10 $20 \%$ in poorly bedded sandstones. Here, clasts are devoid of tectonic foliation, but are typically variably bent, flattened and distorted against harder mineral and lithic grains (e.g. andesitic rock fragments). In thinsection, about half of these peridotite clasts contain translucent red chromite, confirming that this type of peridotite is the source rock for the detrital chromite seen elsewhere in thin-sections. Otherwise, the peridotite clasts contain only coarse chlorite with traces of fine secondary magnetite marking original grain boundaries and internal structures. Only two peridotite clasts have been found with trace relict clinopyroxene.

Detrital mineral grains include angular to euhedral crystals of clinopyroxene, K-feldspar, hornblende, magnetite, angular translucent red chromite and rare but angular garnet. Excluding the chromite, similar phenocrysts also occur in the igneous clasts in the Kabadah Formation, thus confirming their igneous origin, even when there is no attached igneous matrix. They are henceforth termed 'free phenocrysts.' Our sampling indicates that these free phenocrysts amount up to $\sim 15 \%$ of detrital grains. However, one-third of the samples show modes more than double this, with some beds up to $70 \%$. Here, these free phenocrysts become the dominant framework component.

There are other Lower Silurian units in the region with a volcanic provenance similar to the Kabadah Formation, such as the Forbes Group, $70 \mathrm{~km}$ to the south-southwest, which contains fresh clasts of hornblende, feldspar porphyritic intermediate and felsic lavas, along with abundant free phenocrysts of

Figure 2 Distribution of Kabadah Formation (see Figure 1 for location). The grid is $10 \mathrm{~km}$ square. The Kabadah Formation occurs in four belts with the second from the east being continuous and showing the maximum width. The circle radii represent the count of detrital grains of chromite per thin-section, relative to the standard circle of value 10 . The largest circle represents the highest number of chromite grains (95 in one thin-section). Y, Yullundry; B, Buckinbah; +, samples analysed by microprobe. 
hornblende, clinopyroxene, feldspar and volcanic quartz, but peridotite and chromite clasts are unknown.

The Kabadah Formation changes character quite strongly up-sequence (westward) in each thrust slice, both in detrital content and in geophysical (aeromagnetic and radiometric) response. Individual thrust slices of the Kabadah Formation show a westward up-sequence increase in: (i) aeromagnetic intensity from $500 \times 10^{-5}$ to $15000 \times 10^{-5} \mathrm{SIU}$; (ii) intensity of the $\mathrm{K}$ radiometric signature from moderate to strong; (iii) whole-rock $\mathrm{K}$ content, as estimated from $\mathrm{HF}$ etching plus sodium cobaltinitrate staining of hand specimens; and (iv) the modal abundance of mafic volcanic clasts, and in different beds, of free phenocrysts of hornblende, pyroxene, feldspar and magnetite. The strength of these changes varies along strike, and it is most pronounced within, and to the north of, the two key areas. The distribution of various detrital components is summarised in Table 1. Magnetite-rich heavy mineral sands are found at several places, for example in the Yullundry area.

Chromite grains are generally rare in the Kabadah Formation (fewer than six grains per thin-section for $>40 \mathrm{~km}$ strike length), except for two areas (Yullundry and Buckinbah), each about $2 \mathrm{~km}$ across, where there are typically 20-70 grains per thin-section (Figure 2). Regionally, there is no obvious correlation between the number of grains of chromite and the modal abundance of magnetite or lithic grains in the same sample. At Buckinbah, there is a weak correlation between number of grains of chromite and the modal abundance of peridotite clasts (up to $25 \%$ ), but most samples with abundant chromite grains have few peridotite clasts and little detrital magnetite. However, about one-quarter of the Yullundry samples show a correlation between the modal abundance of detrital chromite and magnetite grains in a thin-section $(\sim 4: 1)$.

Detrital metamorphic quartz is a sparse but widely distributed component, in contrast to a minor abundance of detrital volcanic quartz that is restricted to the Buckinbah and Yullundry areas. Clasts of welded rhyolitic tuff have only been found in a single $10 \mathrm{~m}^{2}$ outcrop in the Yullundry area (to $10 \%$ modal and up to $50 \mathrm{~mm}$ in diameter). Other than this minor detritus, the outcrop comprises andesitic volcaniclastic limy sandstone with detrital translucent red chromite. The welded tuff has phenocrysts of garnet and quartz and appears typical of the Early Silurian S-type volcanics (see below).

\section{COMPOSITIONS OF MINERAL AND LITHIC DETRITUS}

\section{Peridotite and chromite clasts}

Microprobe analyses of 38 chromite grains from 10 samples (Table 2) show that the detrital chromites are dominantly refractory compositions $(0.64<\mathrm{Cr} \#<0.93$, $0.39<\mathrm{Fe} \#<0.74$ with low $\mathrm{TiO}_{2}$ contents: Figure 3 ). The highly refractory nature of the Kabadah chromites (average $\mathrm{Cr} \#=0.8$ ) is more characteristic of chromites formed in supra-subduction zone settings than those formed during the petrogenesis of mid-ocean ridge basalts (Dick \& Bullen 1984; Dick \& Natland 1995; Parkinson \& Pearce 1998; Batanova \& Sobolev 2000) and their complementary upper mantle sections. The Kabadah chromite compositions (particularly their low $\mathrm{Al}_{2} \mathrm{O}_{3}$ and $\mathrm{TiO}_{2}$ contents: Kamenetsky et al. 2001), coupled with their common occurrence in chloritised ultramafic clasts, indicate that their protoliths were probably harzburgite or dunite rather than high-Mg arc lavas. Based on the discrimination plot of Kamenetsky et al. (2001) using chromite $\mathrm{Al}_{2} \mathrm{O}_{3}$ and $\mathrm{TiO}_{2}$ contents, peridotite detritus in the Kabadah Formation is most compatible with a source from forearc upper mantle peridotite (Figure 3). Chromites in serpentinites from

Table 1 Distribution of detrital components in Kabadah Formation sandstones.

\begin{tabular}{|c|c|c|}
\hline Detritus/feature & Modal abundance of detritus & Along-strike distribution $(\mathrm{km})$ \\
\hline Mafic lava & $\begin{array}{l}0-80 \% \text { in some beds, increases westward within thrust slices in } \\
\text { some beds }\end{array}$ & 32 \\
\hline Mafic crystals & $\begin{array}{l}15 \% \text { average, increasing westward within thrust slices to } 70 \% \text { in } \\
\text { some beds within and to the north of Buckinbah and Yullundry }\end{array}$ & 35 \\
\hline Hornblende & $\begin{array}{l}\text { Minor, increasing westward within thrust slices to } 20 \% \text { in some } \\
\text { beds }\end{array}$ & 37 \\
\hline Magnetite & $\begin{array}{l}\text { Minor, increasing westward within thrust slices to } 10 \% ; 5 \% \text { and } \\
\text { greater only at Yullundry }\end{array}$ & 35 \\
\hline Total magnetic intensity & $\begin{array}{l}\text { Weak, increasing westward in thrust slices (rising to strong in } \\
\text { western two thrust slices) }\end{array}$ & 50 \\
\hline $\mathrm{K}_{2} \mathrm{O} \mathrm{wt} \%$ & $\begin{array}{l}\text { Estimated from } \mathrm{K} \text { stain in hand specimens, increasing westward } \\
\text { within thrust slices from } 0.5 \text { to } 5 \% \text { (average } 2.7 \% \text { ) }\end{array}$ & 35 \\
\hline K-radiometric signal & High; strongly increasing westward within thrust slices & 50 \\
\hline Peridotite & Up to $45 \%$ in Buckinbah, otherwise average $1 / 2$ grain per sample & 2 \\
\hline Chromite & $<6$ grains/thin-section, but up to 70 in Buckinbah and Yullundry & 25 \\
\hline Quartz & Sparse but widely distributed & 35 \\
\hline Fold Belt & Trace including Buckinbah and Yullundry & 13 \\
\hline Rhyolite & $\begin{array}{l}\text { Absent, except up to } 10 \% \text { in one outcrop at Yullundry (661267E } \\
6364459 \text { N AGD66) }\end{array}$ & - \\
\hline Garnet & Trace, only in Buckinbah and Yullundry & 4 \\
\hline Volcanic quartz & Minor, only in Buckinbah and Yullundry & 4 \\
\hline
\end{tabular}


Table 2 Compositions of detrital chromites in the Kabadah Formation sandstones.

\begin{tabular}{|c|c|c|c|c|c|c|c|c|c|c|c|}
\hline Sample & $\mathrm{TiO}_{2}$ & $\mathrm{Al}_{2} \mathrm{O}_{3}$ & $\mathrm{Cr}_{2} \mathrm{O}_{3}$ & $\mathrm{Fe}_{2} \mathrm{O}_{3}$ & $\mathrm{FeO}$ & $\mathrm{MnO}$ & $\mathrm{MgO}$ & $\mathrm{NiO}$ & Total & Mg\# & $\mathrm{Cr} \#$ \\
\hline KA15-1 & 0.12 & 13.83 & 46.33 & 9.34 & 21.56 & 0.22 & 7.97 & 0.07 & 99.44 & 0.40 & 0.69 \\
\hline KA15-2 & 0.09 & 13.83 & 53.61 & 3.22 & 19.87 & 0.24 & 9.28 & BDL & 100.14 & 0.45 & 0.72 \\
\hline KA15-3 & 0.56 & 13.78 & 57.36 & 0.00 & 16.50 & 0.06 & 11.83 & BDL & 100.08 & 0.56 & 0.74 \\
\hline WELB 1.1 & 0.23 & 19.97 & 43.14 & 6.74 & 21.46 & 0.26 & 9.03 & BDL & 100.83 & 0.43 & 0.59 \\
\hline WELB 1.3 & 0.29 & 18.32 & 42.61 & 8.60 & 22.28 & 0.30 & 8.22 & BDL & 100.62 & 0.40 & 0.61 \\
\hline WELB 2.1 & 0.07 & 10.75 & 55.80 & 4.50 & 19.13 & 0.24 & 9.31 & BDL & 99.80 & 0.46 & 0.78 \\
\hline WELB 2.2 & 0.04 & 10.70 & 55.40 & 5.22 & 19.24 & 0.17 & 9.24 & 0.07 & 100.08 & 0.46 & 0.78 \\
\hline WELB 3.1 & 0.10 & 11.65 & 57.89 & 1.15 & 19.61 & 0.20 & 9.08 & 0.06 & 99.73 & 0.45 & 0.77 \\
\hline WELB 4.1 & 0.12 & 15.30 & 51.11 & 4.64 & 17.80 & 0.21 & 10.66 & 0.08 & 99.91 & 0.52 & 0.69 \\
\hline WELB 5.1 & 0.22 & 14.91 & 42.23 & 12.62 & 23.00 & 0.31 & 7.25 & 0.12 & 100.65 & 0.36 & 0.66 \\
\hline WELB 5.2 & 0.26 & 15.45 & 41.07 & 13.06 & 23.47 & 0.24 & 7.09 & 0.15 & 100.79 & 0.35 & 0.64 \\
\hline WELB 6.1 & 0.10 & 6.89 & 58.27 & 5.24 & 21.58 & 0.29 & 7.13 & 0.08 & 99.58 & 0.37 & 0.85 \\
\hline WELB 7 & 0.01 & 21.59 & 47.48 & 3.44 & 16.55 & 0.13 & 12.53 & 0.10 & 101.82 & 0.57 & 0.60 \\
\hline WELB 8.1 & 0.07 & 10.39 & 60.61 & 0.99 & 15.61 & 0.22 & 11.51 & 0.09 & 99.49 & 0.57 & 0.80 \\
\hline WELB 8.2 & 0.11 & 10.41 & 61.20 & 0.97 & 16.30 & 0.20 & 11.32 & BDL & 100.51 & 0.55 & 0.80 \\
\hline WELB 9.1 & 0.10 & 19.63 & 43.48 & 7.84 & 21.21 & 0.33 & 9.16 & 0.06 & 101.81 & 0.43 & 0.60 \\
\hline WELB 9.2 & 0.11 & 20.55 & 42.22 & 6.85 & 21.16 & 0.27 & 8.94 & 0.08 & 100.17 & 0.43 & 0.58 \\
\hline WELB 10.1 & 0.18 & 13.38 & 50.46 & 7.11 & 22.42 & 0.30 & 7.77 & 0.09 & 101.71 & 0.38 & 0.72 \\
\hline WELB 10.2 & 0.17 & 13.47 & 50.05 & 7.14 & 21.71 & 0.35 & 8.10 & 0.05 & 101.04 & 0.40 & 0.71 \\
\hline WELB 11.1 & 0.16 & 11.67 & 53.66 & 5.50 & 20.09 & 0.23 & 8.88 & 0.05 & 100.24 & 0.44 & 0.76 \\
\hline WELB 12 & 0.20 & 28.60 & 38.51 & 3.56 & 16.27 & 0.14 & 13.17 & 0.14 & 100.59 & 0.59 & 0.47 \\
\hline WEAW 1 & 0.07 & 7.26 & 61.14 & 2.79 & 19.15 & 0.25 & 8.87 & BDL & 99.53 & 0.45 & 0.85 \\
\hline WEAW 1.2 & 0.09 & 7.04 & 60.39 & 3.45 & 19.17 & 0.28 & 8.72 & BDL & 99.15 & 0.45 & 0.85 \\
\hline WEAW 2.2 & 0.19 & 23.68 & 34.72 & 9.89 & 24.93 & 0.59 & 6.77 & BDL & 100.77 & 0.33 & 0.50 \\
\hline WEAW 3.1 & 0.01 & 12.32 & 59.64 & 0.92 & 14.12 & 0.18 & 12.82 & BDL & 100.01 & 0.62 & 0.76 \\
\hline WEAW 3.2 & 0.01 & 12.55 & 58.78 & 1.18 & 14.65 & 0.36 & 12.12 & $\mathrm{BDL}$ & 99.65 & 0.60 & 0.76 \\
\hline WEAW 4.1 & 0.04 & 14.67 & 53.77 & 2.36 & 17.74 & 0.35 & 10.38 & 0.07 & 99.38 & 0.51 & 0.71 \\
\hline WEAW 5 & 0.02 & 15.28 & 51.85 & 4.17 & 18.46 & 0.25 & 10.21 & 0.07 & 100.32 & 0.50 & 0.69 \\
\hline WEAW 7.1 & 0.04 & 11.39 & 60.60 & 0.71 & 16.69 & 0.21 & 11.22 & $\mathrm{BDL}$ & 100.86 & 0.55 & 0.78 \\
\hline WEAW 7.3 & 0.03 & 11.16 & 60.65 & 0.88 & 14.90 & 0.46 & 11.99 & 0.08 & 100.15 & 0.59 & 0.78 \\
\hline WEAW 8 & 0.19 & 8.76 & 55.84 & 5.25 & 21.82 & 0.49 & 7.15 & BDL & 99.51 & 0.37 & 0.81 \\
\hline
\end{tabular}

BDL, below detection limit. $\mathrm{Fe}_{2} \mathrm{O}_{3}$ assigned on basis of stoichiometry.

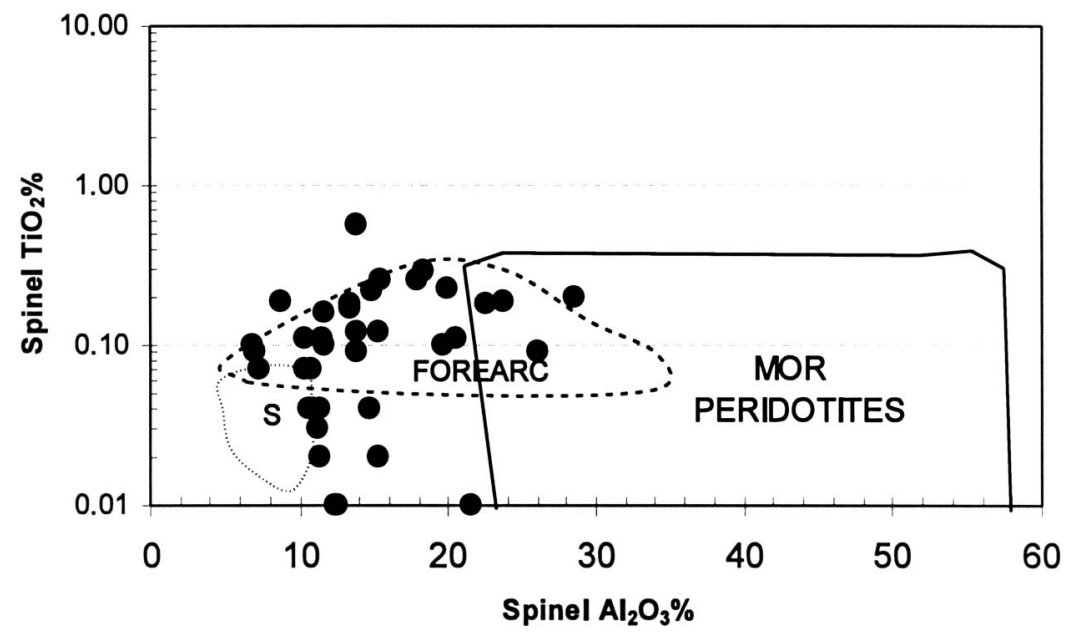

Figure 3 Chromite discrimination diagram proposed by Kamenetsky et al. (2001) to distinguish chromites in peridotites from those in lavas (lava fields not shown), and to distinguish between chromites in forearc harzburgitic peridotites from those in peridotites in typical ridge-generated oceanic settings (MOR). Also shown (fine dotted field S) is the field for chromites from serpentinites occurring along major faults in the Snowy Mountains in southeast New South Wales (from Kamenetsky et al. 2001).

thin ophiolite slices in the Snowy Mountains, the latter likely to have been emplaced during the same Benambran collisional event, show compositions marginal to the Kabadah chromites (Figure 3) (Kamenetsky et al. 2001).
The detrital peridotite clasts typically do not show any tectonic foliation. However, the local bending and flattening of peridotite clasts against harder andesitic clasts and mineral grains suggests that they were chloritised before being deposited. In support of this 
interpretation is that thousands of mantle clasts found in 14 of 28 samples in the Buckinbah area showed identical chlorite-alteration. The coarse nature and perfect crystallinity of the chlorite indicate alteration of the source rock under unusual circumstances, namely uniform prolonged conditions at temperatures high enough to make chlorite but not serpentine + magnetite. Chlorite is rare in the mantle portions of ophiolites. Furthermore, wholesale chlorite-overprinting of obducted mantle has not been reported in clasts derived from ophiolites (P. Garzanti pers. comm. 2003). Despite the highly refractory nature of the Kabadah chromite, the chromite-bearing mantle clasts are not derived from a typical ophiolite because of the: (i) absence of serpentine minerals (serpentinite) in the peridotite clasts; (ii) complete overprinting of silicate minerals in thousands of observed Kabadah mantle clasts by coarse chlorite; and (iii) absence of other typically ophiolitic detritus, such as gabbros and pyroxenites. For example, in modern sands derived by erosion of the Cyprus and Oman ophiolites, gabbroic detritus overwhelmingly dominates, whereas serpentinite clasts are a minor component (Garzanti et al. 2000, 2002). Some ophiolites are dominated by mantle lithologies (such as in New Caledonia and Japan), but these rocks typically alter via serpentinisation so could not contribute only chlorite-altered mantle clasts.

Most altered peridotites from modern forearc mantle diapirs are typically serpentinised. However, Hussong and Fryer (1981) reported extensive chloriteoverprinting in modern forearc mantle diapirs located $<50 \mathrm{~km}$ from a subduction trench in the Mariana forearc region. They noted that these diapirs lack the strong magnetic signature of the serpentinite-bearing variety, suggesting that chlorite-alteration of the diapir was pervasive and a characteristic feature. On this basis, we suggest that the most likely source of the Kabadah mantle peridotite detritus is from a near-trench forearc-mantle diapir. Such a diapir (in a deep-marine setting) could not contribute directly to Early Silurian shallow-marine sedimentation: more probably, it was older, probably Ordovician, and re-exposed in the Early Silurian.

\section{Detrital clinopyroxenes}

Compositions of 71 clinopyroxene grains (including detrital grains and phenocrysts in mafic lava clasts) were measured using an electron microprobe. All have relatively high $\mathrm{Na}_{2} \mathrm{O}$ and $\mathrm{Al}_{2} \mathrm{O}_{3}$ contents (Figure 4; Table 3). The reference fields shown on Figure 4 are relevant for considering possible sources of mafic igneous detritus available during the Early Silurian. These include the Molong Volcanic Belt (closest adjacent part of the Ordovician Macquarie Arc), Early Silurian monzodioritic intrusives and their host Wombin Volcanics felsic lavas of the June-Narromine Volcanic Belt, and the Owendale complex (representative of the Early Silurian Fifield Alaskan-type complexes occurring west of the Junee-Narromine Volcanic Belt: Crawford et al. 2007). The Kabadah pyroxene data show a correlation between $\mathrm{Na}_{2} \mathrm{O}$ and $\mathrm{Al}_{2} \mathrm{O}_{3}$ that differs from all of the reference fields on Figure 4 but is closest to the fields of the Owendale complexes. Furthermore, they are unlike

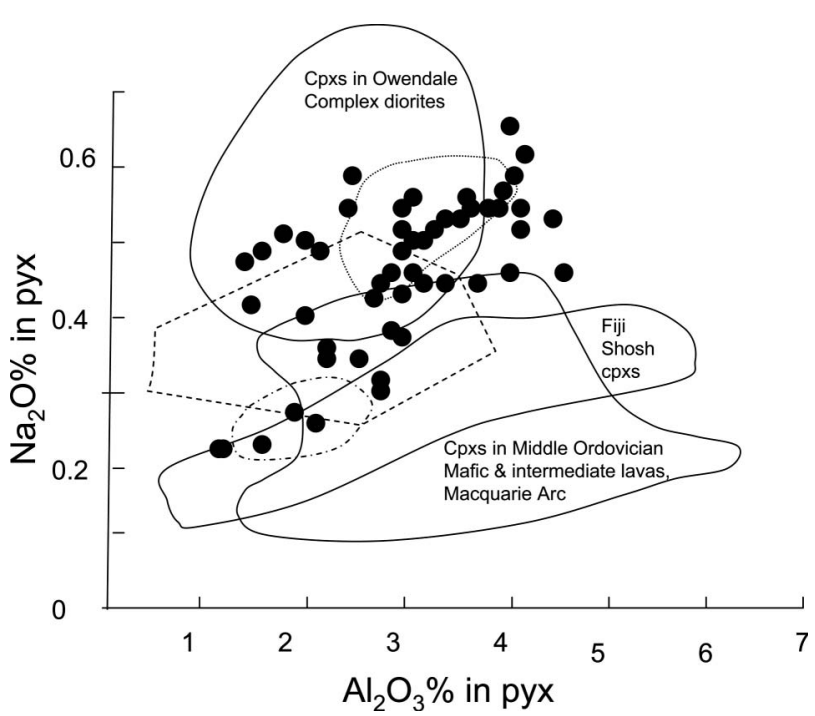

Figure $4 \mathrm{Na}_{2} \mathrm{O}$ vs $\mathrm{Al}_{2} \mathrm{O}_{3}$ compositions of detrital clinopyroxenes from Kabadah Formation sandstones. Dots are detrital pyroxenes, and the dotted field is for clinopyroxene phenocrysts within andesite clasts in the Kabadah Formation. The field for pyroxenes from several Middle Ordovician volcanic formations (Fairbridge, Oakdale and Byng Volcanics) in the Molong Volcanic Belt is derived from unpublished data of Duerden (1999) and S. Meffre (pers. comm. 2001). The dashed polygon field is for 77 analyses of clinopyroxenes from Late Ordovician Wombin Volcanics and Early Silurian felsic intrusives in the Wombin Volcanics (A. J. Crawford unpubl. data). Also shown are fields for feldspathic (mainly monzodiorites) and ultramafic rocks (dot-dash field) from the Early Silurian Owendale Complex (Barron 1988; Barron et al. 2004), and for 110 clinopyroxenes from Fijian Miocene volcanics (mainly basaltic to andesitic compositions; A. J. Crawford unpubl. data).

clinopyroxene phenocrysts $\left(\mathrm{Na}_{2} \mathrm{O}>0.35 \mathrm{wt} \%\right)$ in Miocene Fijian shoshonitic volcanics (Figure 4: data supplied by A. J. Crawford pers. comm. 2004), suggesting that typical shoshonitic lavas such as are common in the volcanic sections of the adjacent volcanic belts (Crawford et al. 2007) are not the source. It may be possible that some of the detrital clinopyroxenes in the Kabadah Formation derived from now-eroded volcanic counterparts of the Fifield Complexes, which we believe were likely to have been compositionally similar to the Nash Hill Volcanics (see Crawford et al. 2007). The latter outcrop just east and southeast of Parkes, are often strongly clinopyroxene-phyric, and are significantly more sodic and LILE-enriched than the shoshonitic Goonumbla and Wombin Volcanics.

\section{Mafic lava clasts}

Whole-rock analyses (Table 4) of two clasts of mafic lava in Kabadah conglomerate are highly potassic, characterised by very high levels of, $\mathrm{P}_{2} \mathrm{O}_{5}, \mathrm{Ba}, \mathrm{Sr}, \mathrm{Sr} / \mathrm{Y}$, Th, LREE and $\mathrm{K}_{2} \mathrm{O}$, the latter probably responsible for the prominent $\mathrm{K}$ signature in the radiometric data. Although classifying as shoshonitic, this enrichment in K-group elements is more pronounced than in most lavas of the adjacent Molong Volcanic Belt, including 
Table 3 Representative microprobe analyses of detrital clinopyroxenes in Kabadah Formation sandstones.

\begin{tabular}{|c|c|c|c|c|c|c|c|c|c|c|}
\hline Sample & $\mathrm{SiO}_{2}$ & $\mathrm{TiO}_{2}$ & $\mathrm{Al}_{2} \mathrm{O}_{3}$ & $\mathrm{FeO}$ & $\mathrm{MnO}$ & $\mathrm{MgO}$ & $\mathrm{CaO}$ & $\mathrm{Na}_{2} \mathrm{O}$ & Total & $\mathrm{Mg \#}$ \\
\hline KA7cpxl.2 & 51.75 & 0.43 & 2.52 & 7.08 & 0.44 & 14.94 & 21.74 & 0.44 & 99.34 & 0.79 \\
\hline KA7cpx2A & 51.59 & 0.44 & 2.63 & 7.06 & 0.36 & 14.96 & 21.29 & 0.45 & 98.78 & 0.79 \\
\hline KA7срх3.2 & 50.11 & 0.45 & 3.37 & 7.56 & 0.19 & 14.41 & 21.88 & 0.39 & 98.36 & 0.77 \\
\hline KA7cp03 & 51.74 & 0.41 & 2.56 & 7.22 & 0.41 & 14.76 & 21.57 & 0.60 & 99.27 & 0.78 \\
\hline KA7cpx4A & 50.41 & 0.59 & 3.43 & 7.44 & 0.48 & 14.29 & 21.81 & 0.52 & 98.97 & 0.77 \\
\hline KA7cpx41 & 51.55 & 0.41 & 2.28 & 7.18 & 0.45 & 15.13 & 21.47 & 0.48 & 98.95 & 0.79 \\
\hline KA7cpx43rim & 50.01 & 0.61 & 3.78 & 7.79 & 0.43 & 14.16 & 21.24 & 0.61 & 98.63 & 0.76 \\
\hline KA7cpx4.5 & 51.51 & 0.43 & 2.56 & 7.19 & 0.40 & 14.99 & 21.37 & 0.58 & 99.03 & 0.79 \\
\hline KA 15 срхA2 & 50.63 & 0.40 & 2.85 & 6.84 & 0.31 & 14.71 & 22.89 & 0.56 & 99.19 & 0.79 \\
\hline KA 15 срхA3 & 49.89 & 0.68 & 3.96 & 7.69 & 0.38 & 13.85 & 22.51 & 0.55 & 99.51 & 0.76 \\
\hline KA 15 cpxA & 50.02 & 0.57 & 3.40 & 8.07 & 0.35 & 14.29 & 22.74 & 0.54 & 99.98 & 0.76 \\
\hline KA 15 срх2 & 49.57 & 0.58 & 3.81 & 8.23 & 0.39 & 13.56 & 21.86 & 0.57 & 98.57 & 0.75 \\
\hline KA 15 cpxl1 & 50.70 & 0.47 & 3.09 & 7.44 & 0.25 & 14.10 & 21.86 & 0.52 & 98.43 & 0.77 \\
\hline KA 15 сpx13 & 50.90 & 0.37 & 2.79 & 6.95 & 0.27 & 14.55 & 21.90 & 0.52 & 98.25 & 0.79 \\
\hline WEAW 5 cpxl & 49.12 & 0.73 & 4.28 & 9.00 & 0.30 & 13.44 & 21.27 & 0.54 & 98.68 & 0.73 \\
\hline WEAW 5 cpx 4 & 51.03 & 0.65 & 2.64 & 6.72 & 0.12 & 15.17 & 22.42 & 0.30 & 99.05 & 0.80 \\
\hline WEAW 5 cpx9 & 49.85 & 0.94 & 3.24 & 8.55 & 0.47 & 13.99 & 20.67 & 0.46 & 98.17 & 0.74 \\
\hline WEAW 5 cpx12 & 51.56 & 0.40 & 2.04 & 5.64 & 0.16 & 15.57 & 22.48 & 0.26 & 98.11 & 0.83 \\
\hline WEAW 5 cpx15 & 50.94 & 0.74 & 2.31 & 8.09 & 0.58 & 13.35 & 22.41 & 0.60 & 99.02 & 0.75 \\
\hline WELB 1 cpx5 & 49.70 & 0.60 & 4.01 & 8.17 & 0.39 & 13.54 & 21.33 & 0.62 & 98.36 & 0.75 \\
\hline WELB 1 cpx 6 & 50.69 & 0.51 & 3.17 & 7.67 & 0.33 & 13.89 & 21.57 & 0.54 & 98.37 & 0.76 \\
\hline WELB 1 cpx7 & 50.87 & 0.47 & 2.87 & 8.01 & 0.35 & 14.38 & 21.50 & 0.57 & 99.02 & 0.76 \\
\hline 0r56cpx1A & 50.94 & 0.50 & 2.98 & 8.23 & 0.44 & 14.38 & 20.58 & 0.46 & 98.51 & 0.76 \\
\hline 0r56cpx2 & 51.72 & 0.43 & 1.86 & 7.98 & 0.46 & 15.23 & 20.73 & 0.41 & 98.82 & 0.77 \\
\hline 0r56cpA & 51.24 & 0.46 & 2.11 & 7.97 & 0.38 & 14.91 & 20.85 & 0.36 & 98.28 & 0.77 \\
\hline 0r56cpx5 & 50.87 & 0.46 & 2.58 & 9.12 & 0.44 & 14.58 & 20.47 & 0.43 & 98.95 & 0.74 \\
\hline 0r56cpA & 51.91 & 0.23 & 1.69 & 8.31 & 0.67 & 13.84 & 21.28 & 0.52 & 98.45 & 0.75 \\
\hline 0r56cpx9 & 50.85 & 0.58 & 2.87 & 8.07 & 0.43 & 14.69 & 20.73 & 0.43 & 98.65 & 0.76 \\
\hline 0r56cpx14 & 51.86 & 0.26 & 1.56 & 7.59 & 0.66 & 13.96 & 22.11 & 0.39 & 98.39 & 0.77 \\
\hline 0r56cpx18 & 52.15 & 0.20 & 1.31 & 8.12 & 0.69 & 14.22 & 21.66 & 0.48 & 98.83 & 0.76 \\
\hline
\end{tabular}

the Upper Ordovician shoshonitic volcanics (e.g. Cheesemans Creek Formation or Forest Reefs Volcanics: Crawford et al. 2007). They match well the distinctive Th-rich, shoshonitic volcanics Nash Hill Volcanics (A. J. Crawford pers. comm. 2007).

\section{Felsic lithic clasts}

The felsic welded-tuff clasts in the Kabadah Formation appear identical to the cordierite + garnet-bearing felsic S-type volcanics of the subaerial to shallow-water Lower Silurian Canowindra Volcanics that formed by largescale subaerial ignimbritic eruptions in the Cowra Trough. The Canowindra Volcanics are presently adjacent to the Kabadah Formation but extend $50 \mathrm{~km}$ to the south and $50 \mathrm{~km}$ farther north. However, the low abundance and quite restricted distribution of detrital volcanic quartz and clasts of welded rhyolitic tuff in the Kabadah Formation is not consistent with their deposition being synchronous with these Canowindra ignimbritic eruptions.

Doubt as to the uplifted Canowindra Volcanics being the source for some of the Kabadah Formation is also cast by its stratigraphic occurrence between two deep-water graptolitic units-the underlying Gospel Oak Formation and the overlying Avoca Valley Shale (Pogson \& Watkins 1998; Meakin \& Morgan 1999). These suggest that the Canowindra Volcanics are a late Llandovery to early Wenlock ( $c a 428 \mathrm{Ma}$ ) unit, younger than the Kabadah Formation. However, it is possible that some of the Canowindra Volcanics may be older than the given fossil ages, since Pogson and Watkins (1998) reported a U/Pb zircon SHRIMP age of $432 \pm 7 \mathrm{Ma}$ (using zircon AS3 as standard) for a sample of Canowindra Volcanics. Alternatively, there may have been an older felsic volcanic unit, petrographically akin to the Canowindra Volcanics, that is no longer preserved or which has been mapped as Canowindra Volcanics. The key point is that felsic volcanics like the Canowindra Volcanics had been erupted and uplifted, either in an early stage of basin inversion in the second phase of the Benambran Orogeny (Glen et al. 2007), or during renewed extension in the Cowra Trough and eroded at the time the Kabadah Formation was being deposited.

\section{DISCUSSION}

The distinctive detritus in the Kabadah Formation, including chloritised peridotite clasts, common detrital chromite, detrital clinopyroxene compositions, and the extremely K-rich lava clasts, suggests that much of this detritus was not derived from adjacent parts of the Ordovician Macquarie Arc. Nor is the more distant Lower Silurian Fifield belt of Alaskan-type complexes appropriate as an only source. The closest match for the two analysed lithic clasts appears to be the Lower Silurian Nash Hill Volcanics, now restricted to several narrow fault-bounded slices east of the Parkes Thrust, 
Table 4 Whole-rock analyses of porphyritic mafic volcanic clasts from Kabadah Formation (GR AGD66 661950 N 6362120 N).

\begin{tabular}{lcc}
\hline & $\mathrm{KA} 7$ & $\mathrm{KA} 8$ \\
\hline $\mathrm{SiO}_{2}$ & 53.69 & 49.88 \\
$\mathrm{TiO}_{2}$ & 0.64 & 0.76 \\
$\mathrm{Al}_{2} \mathrm{O}_{3}$ & 15.54 & 14.16 \\
$\mathrm{Fe}_{2} \mathrm{O}_{3}$ & 8.74 & 10.91 \\
$\mathrm{MnO}$ & 0.17 & 0.21 \\
$\mathrm{MgO}$ & 3.93 & 5.64 \\
$\mathrm{CaO}$ & 5.53 & 7.22 \\
$\mathrm{Na} \mathrm{O}_{2} \mathrm{O}$ & 2.03 & 1.54 \\
$\mathrm{~K}_{2} \mathrm{O}$ & 7.75 & 6.44 \\
$\mathrm{P}_{2} \mathrm{O}_{5}$ & 0.53 & 0.64 \\
$\mathrm{LOI}$ & 1.02 & 2.12 \\
$\mathrm{Total}$ & 99.57 & 99.52 \\
$\mathrm{Ba}$ & 4953 & 5161 \\
$\mathrm{Ce}$ & 135 & 132 \\
$\mathrm{Cr}$ & 17 & 52 \\
$\mathrm{Cu}$ & 109 & 132 \\
$\mathrm{La}$ & 68 & 71 \\
$\mathrm{Nb}$ & 12.5 & 8.2 \\
$\mathrm{Nd}$ & 61 & 67 \\
$\mathrm{Ni}$ & 8 & 15 \\
$\mathrm{~Pb}$ & 10 & 7 \\
$\mathrm{Rb}$ & 126 & 94 \\
$\mathrm{Sc}$ & 18 & 23 \\
$\mathrm{Sr}$ & 2157 & 504 \\
$\mathrm{Th}$ & 9.7 & 20 \\
$\mathrm{~V}$ & 258 & 106 \\
$\mathrm{Y}$ & 18 & \\
$\mathrm{Zn}$ & 88 & \\
$\mathrm{Zr}$ & 142 & \\
& & \\
& &
\end{tabular}

although a significant contribution of detrital pyroxene from the Lower Silurian Fifield complexes cannot be ruled out on available data.

Free crystals of pyroxene and hornblende may have been derived from the erosion of mafic volcanics, by the disintegration of hot lava through interaction with seawater, or by coeval airfall of tuffaceous material. The free phenocrysts of clinopyroxene and hornblende increase westward in each Kabadah thrust slice, and this sudden increase does not correspond with a sudden change in the porphyritic character of the volcanic source material, as judged by the accompanying lithic clasts.

\section{Fifield complexes and a Fifield arc?}

The Fifield complexes intrude a deformed basement (comprising Ordovician Girilambone Group turbidites assembled by the Benambran Orogeny) and geological and geochemical evidence (Barron et al. 2004; Crawford et al. 2007; Glen et al. 2007) suggests an Early Silurian age of emplacement. Based on geology, platinum mineralisation, and whole-rock/mineral geochemistry, the Fifield complexes are interpreted to be Alaskan complexes (Bowman et al. 1982; Barron et al. 1991, 2004; Johan 2002). Murray (1972) suggested that Alaskan complexes were the feeder pipes for arc volcanoes. Despite their large size (4-25 km across), many of the Fifield complexes have significant volumes of fine-grained rocks, indicating high-level emplacement. Phenocrysts in the Fifield Alaskan complexes formed at relatively high crystallisation pressures (to $800 \mathrm{MPa}$ ), resulting in elevated levels of jadeitic $\mathrm{NaAl}$ component in the pyroxene (Johan 2002) and an elevated level of Al component in coexisting hornblende (Barron et al. 1991, 2004; Kepezhinskas et al. 1993). According to Barron et al. $(1991,2004)$, the Owendale complex has the lowest pressure (300-500 MPa) of crystallisation for phenocrysts of any of the Fifield complexes studied to date, while the adjacent Tout complex has the highest $(500-800 \mathrm{MPa})$.

Although more detailed research is required, it is possible that the Fifield complexes represent feeders to Early Silurian arc-type volcanoes from which were erupted the distinctive shoshonitic lavas of the Nash Hill Volcanics (and their now-eroded equivalents). This postulated Fifield volcanic arc has the right age, setting, location and chemistry to be a significant part of the Kabadah provenance. However, the Fifield arc must have been emergent for only a very short time, since (i) there are only modest volumes of mafic volcanic detritus in any of the Early Silurian marine horizons in this part of the Lachlan Orogen, and (ii) their intrusive parts (Fifield complexes) had been exhumed by the Late Silurian (Barron et al. 1991; Sherwin 1996), requiring rapid removal of the volcanic edifice by erosion.

Such a short period of arc activity probably reflects a short period of subduction and is consistent with subduction of crust of a small backarc basin.

\section{Tectonic setting of the Kabadah Formation}

In general, there appears to have been a link between the distribution and amount of different types of detritus shed into the Kabadah Formation, and this provides important tectonic clues. For example, it is only in the uppermost, shallow-water part of the unit that felsic volcanic and mantle-derived peridotite detritus are very common. The Buckinbah area has more chromite and all of the mantle clasts, while the Yullundry area has the only known occurrence of clasts of welded S-type rhyolitic tuff. This upward change coincides with a strong increase in free phenocrysts. Two synchronous but separate and small short-term proximal sources are required, perhaps triggered by the same tectonic event.

The following tectonic scenario is suggested for the Kabadah Formation.

(1) The multiphase Benambran Orogeny terminated the Benambran cycle of the Lachlan Orogen at the end of the Ordovician (Glen 2005; Glen et al. 2007), uplifting and juxtaposing Ordovician quartz-rich turbidites of the Adaminaby Superterrane (Glen 2005), such as the Girilambone Group and its substrate of ocean floor basalt to the west, against Macquarie Arc rocks to the east (Glen et al. 2007).

(2) Relaxation or extension after phase I of the Benambran Orogeny (Glen et al. 2007) resulted in basin formation, including that in which the Kabadah Formation accumulated, as well as silicic volcanism. The basin in which the Kabadah Formation accumulated, the Kabadah Basin, probably formed as a transient basin rather than an early stage of the Cowra Trough. 
(3) At the same time as (2), the Early Silurian Fifield Alaskan complexes were emplaced as feeder pipes to a short-lived emergent arc (Barron et al. 2004) built on the deformed, overthrust Girilambone Group and the underthrust Macquarie Arc (Glen et al. 2002). Rapid exhumation of these Fifield complexes probably contributed detritus into the Kabadah Basin. Other possible sources included volcanics associated with the Fifield complexes, represented by the Early Silurian Nash Hill Volcanics, and minor volcaniclastic detritus may also be derived from erosion of the deformed Macquarie Arc.

(4) Initiation of the Fifield arc required subduction of the Wagga Basin that may have formed an older backarc basin to the Early-Middle Ordovician stages of the Macquarie Arc (Meffre et al. 2007).

(5) The Kabadah Basin also received minor detritus from recently erupted S-type felsic volcanic rocks no longer preserved (perhaps an early stage of the Canowindra Volcanics) as well as the uplifted Girilambone Group to the west. The up-sequence increase in abundance and distribution of the phenocryst-rich airfall detritus from the Fifield arc and the felsic and mantle peridotitic detritus is consistent with these sources being transported structurally towards the Kabadah Basin with time.

(6) The short-lived Fifield arc was terminated by renewed collision in phase II of the Benambran Orogeny (Glen et al. 2007), uplifting the Kabadah Basin and ending deposition of the Kabadah Formation.

(7) This younger uplift is reflected in the presence of fresh clasts of hornblende + feldspar porphyritic trachyte and latite, along with abundant free phenocrysts of hornblende, clinopyroxene, feldspar and volcanic quartz in the Kabadah Formation and in the Forbes Group, $70 \mathrm{~km}$ south-southwest of the Kabadah Formation.

(8) As a result of multiple thrusting in the Benambran Orogeny, the Kabadah Formation was stacked above the (younger) Canowindra Volcanics, and this combined package was thrust eastwards over the units of the Macquarie Arc preserved in the Molong Volcanic Belt, the Gunnars Dam beds and the Oakdale Formation.

The Kabadah Formation was originally interpreted by Morgan et al. (1999) as a volcaniclastic unit of the Ordovician Macquarie Arc. However, the presence of key fossils indicates that it is Early Silurian and therefore not derived from the Macquarie Arc while it was active. Furthermore, the absence of key Kabadah detritus from Ordovician rocks in the central part of New South Wales (Macquarie Arc volcaniclastics, Girilambone Group quartz-rich turbidites) requires the first appearance of the sources of mantle peridotites, felsic volcanics and fold belt detritus to be in the Early Silurian.

\section{CONCLUSIONS}

The Lower Silurian Kabadah Formation was deposited in a shallow-marine basin between phases I and II of the Benambran Orogeny. Aside from possible minor debris from the Ordovician parts of the Macquarie Arc, detritus in the Kabadah Formation was derived from Early Silurian intrusives/extrusives, uplifted Girilambone
Group, from upthrust parts of Early Silurian felsic volcanics (an early phase of the Canowindra Volcanics, or from an older now-eroded unit) and from an exhumed mantle diapir cold-emplaced in the forearc of the shortlived Fifield arc. This complex provenance required local subduction of the former backarc Wagga Basin, creating the short-lived emergent Fifield arc, with the Alaskan complexes as feeder pipes to the arc volcanoes. Towards the end of deposition of the upper Kabadah Formation, the Fifield arc was thrust east towards the Kabadah Formation, as part of phase II of the Benambran Orogeny, leading to closure of the Kabadah Basin. Subsequent deformation caused imbrication of the Kabadah Formation with the Canowindra Volcanics and with Ordovician volcaniclastic units of the Macquarie Arc.

\section{ACKNOWLEDGEMENTS}

Ervin Slanksy identified clinochlore by XRD as the dominant mineral in the altered peridotite clasts. This work was initiated as part of the Dubbo mapping and completed as part of the CODES-DMR SPIRT project. The manuscript benefited from comments by A. J. Crawford, G. Packham, L. Sherwin and an anonymous reviewer. LMB and RAG publish with permission of the Deputy Director General Primary IndustriesMineral Resources.

\section{REFERENCES}

BARRON L. M. 1988. Platinum project: petrology and chemistry of rocks. Geological Survey of New South Wales Report GS1987/298 (unpubl.).

Barron L. M., Ohnenstetter M., Barron B. J., Suppel D. W. \& FALLOON T. 2004. Geology of the Fifield Alaskan-type complexes, New South Wales, Australia. Geological Survey of New South Wales Report GS2004/323 (unpubl.)

BARRon L. M., SupPel D. W., Slansky E., Johan Z., OHNEnStetTer M. \& SPENCER R. 1991. The Fifield platinum province. Geological Society of Australia Abstracts 29, 3 .

BARRON L. M. \& WARREN A. W. 1998. Ultramafic detritus in the Late Ordovician Kabadah Beds at Yallundry. Geological Survey of New South Wales Report GS1998/162 (unpubl.).

BATANOVA V. G. \& SoBOLEV A. V. 2000. Compositional heterogeneity in subduction-related mantle peridotites, Troodos massif, Cyprus. Geology 28, 55-84.

BOWMAN H. N., RICHARDSON S. J. \& DOLANSKI J. 1982 Narromine 1:250 000 Metallogenic Map SI/55-3: Mine Data Sheets and Metallogenic Study. Geological Survey of New South Wales, Sydney.

Crawford A. J., MefFre S., SQUiRe R. J., BARRon L. M. \& FALlOON T. J. 2007. Middle and Late Ordovician magmatic evolution of the Macquarie Arc, Lachlan Orogen, New South Wales. Australian Journal of Earth Sciences 54, 181-214.

DiCK H. J. B. \& BULLEN T. 1984. Chromium spinel as a petrogenetic indicator in abyssal and alpine-type peridotites and spatially associated lavas. Contributions to Mineralogy and Petrology $\mathbf{8 6}$, $54-76$.

Dick H. J. B. \& NATLAND J. H. 1995. Late stage melt evolution and transport in the shallow mantle beneath the East Pacific Rise. Proceedings of the Ocean Drilling Program Scientific Results $\mathbf{1 7 6}$ $103-134$.

DUERDEN P. B. 1999. Lithostratigraphy and lithogeochemistry of Ordovician volcano-plutonic rocks Central Molong Belt, NSW. BSc (Hons) thesis, University of Tasmania, Hobart (unpubl.). 
GARZANTI E., ANDO S. \& Scutella M. 2000. Actualistic ophiolite provenance: the Cyprus case. Journal of Geology 108, 199-218.

GARZANTI E., VEZZOLI G. \& ANDO S. 2002. Modern sand from obducted ophiolite belts (Sultanate of Oman and United Arab Emirates). Journal of Geology 110, 371-391.

GLEN R. A. 2005. The Tasmanides of Eastern Australia. In: Vaughan A., Leat P. \& Pankhurst R., eds. Terrane Processes at the Margins of Gondwana. pp. 23-96. Geological Society of London Special Publication 246.

Glen R. A., Korsch R. J., Direen N. G., Jones L. E. A., Johnstone D. W., LAWRiE J. C., Finlayson D. M. \& SHAW R. D. 2002. Crustal structure of the Ordovician Macquarie Arc, Eastern Lachlan Orogen, based on seismic-reflection profiling. Australian Journal of Earth Sciences 49, 323-348.

Glen R. A., MefFre S. \& SCOTT R. J. 2007. Benambran Orogeny in the Eastern Lachlan Orogen, Australia. Australian Journal of Earth Sciences 54, 385-415.

Hussong D. M. \& FRYER P. 1981. Structure and tectonics of the Mariana arc and forearc. Drill site selection surveys. Initial Reports of the Deep Sea Drilling Project 60, 34-44.

JoHAN Z. 2002. Alaskan-type complexes and their platinum-group element mineralisation. In: Cabri L. J. ed., The Geology, Geochem istry, Mineralogy and Mineral Beneficiation of Platinum-Group Elements. pp. 699-719. Canadian Institute of Mining, Metallurgy and Petroleum Special Volume $\mathbf{5 4 .}$

KAMENETSKY V. S., CRAWFORD A. J. \& MEFFRE S. 2001. Factors controlling chemistry of magmatic spinel: an empirical study of associated olivine, Cr-spinel and melt inclusions from primitive rocks. Journal of Petrology 42,655-671.

KEPEZHINSKAS P., TAYLOR R. N. \& TANAKA H. 1993. Geochemistry of plutonic spinels from the North Kamchatka Arc: comparisons with spinels from other tectonic settings. Mineralogical Magazine 57, 575-589.

MEAKIn S. M. \& MoRGAn E. 1999. Dubbo 1:250 000 Geological Sheet I/ 55-4, 2nd Edition. Explanatory Notes. Geological Survey of New South Wales, Sydney.

\section{APPENDIX 1: TECHNIQUES}

Mineral and rock components were visually identified and estimated for grainsize and modal abundance in 142 thin-sections from the Kabadah Formation, using a petrological microscope. Chromite was identified as translucent isotropic grains under high-intensity lighting at $100 \times$ magnification and was found in 109 thinsections. The chromite counts reported herein represent the number of grains of chromite found on a standard $5 \times 2.5 \mathrm{~cm}$ thin-section. The chromite grains in many of the mantle peridotite clasts show microfracturing and separation of subgrain pieces in a background of chlorite. Only one chromite grain was counted in such cases.

Chlorite, the main component of black peridotite clasts, was provisionally identified by colour and
MefFre S., SCOTT R. J., GLEN R. A. \& SQUIRE R. J. 2007. Re-evaluation of contact relationships between Ordovician volcanic belts and the quartz-rich turbidites of the Lachlan Orogen. Australian Journal of Earth Sciences 54, 363-383.

Morgan E. J., WARREN A. Y. E. \& Henderson G. A. M. 1999. Kabadah Formation. In: Meakin S. M. \& Morgan E. eds. Dubbo 1:250 000 Geological Sheet I/55-4, 2nd Edition. Explanatory Notes, pp. 5558. Geological Survey of New South Wales, Sydney.

MURRAY C. G. 1972. Zoned ultramafic complexes of the Alaskan-type: feeder pipes of andesitic volcanoes. Geological Society of America Memoir 132, 313-335.

PARKInSON I. J. \& PEARCE J. A. 1998. Peridotites from the Izu-BoninMariana forearc (ODP Leg 125): evidence from mantle melting and melt-mantle interaction in a supra-subduction zone setting. Journal of Petrology 39, 1577-1618.

Percival I. G. \& GLen R. A. 2007. Ordovician to earliest Silurian history of the Macquarie Arc, Lachlan Orogen, New South Wales. Australian Journal of Earth Sciences 54, 143-165.

Pogson D. J. \& WATKINS J. W. 1998. Bathurst 1:250 000 Geological Sheet SI/55-8: Explanatory Notes. Geological Survey of New South Wales, Sydney.

Scott M. M., Raymond O. L., Henderson G. A. M., Morgan E., WARREN A. Y. E. \& WYBORN D. 1997. Wellington 1:100 000 Geological Sheet 8632, 1st Edition. Geological Survey of New South Wales, Sydney and Australian Geological Survey Organisation, Canberra.

SHERWIN L. 1996. Narromine 1:250 000 Geological Sheet SI/55-3, Explanatory Notes. Geological Survey of New South Wales, Sydney.

Received 17 October 2003; accepted 17 December 2006

hardness in thousands of clasts in 30 hand specimens, and by optics in a total of 44 thin-sections. Powder extracted from six black clasts in one sample from the Buckingbah area was examined by XRD, verifying that the black clasts contain superbly crystallised clinochlore (Mg-rich tri-octehedral chlorite) as the dominant mineral.

Mineral analyses were undertaken on polished thinsections using a Cameca SX50 microprobe at the University of Tasmania. Whole-rock XRF analysis was undertaken at the University of Tasmania on two mafic cobbles from a conglomerate at one locality in the Kabadah Formation. For details of the methods used, see Crawford et al. (2007).

\section{APPENDIX 2: GRID REFERENCES (AGD66) FOR SANDSTONE SAMPLES}

\begin{tabular}{lcc}
\hline Sample no. & Easting & Northing \\
\hline KA 7 & 661950 & 6362120 \\
KA 8 & 661950 & 6362120 \\
KA 15 & 662400 & 6370400 \\
Or56 & 659840 & 6351920 \\
WELB 1-2 & 664270 & 6373650 \\
WELB 3-7 & 663220 & 6369250 \\
WELB 8-12 & 665020 & 6376740 \\
WEAW 1-4 & 659790 & 6351550 \\
WEAW 5-8 & 662120 & 6362550 \\
\hline
\end{tabular}

